Revue

de Sémantique

et Pragmatique
Revue de Sémantique et Pragmatique

40 | 2016

Exclamation et intersubjectivité

\title{
Exclamatives, Normalcy Conditions and Common Ground
}

\section{Franz d'Avis}

\section{(2) OpenEdition \\ 1 Journals}

Electronic version

URL: http://journals.openedition.org/rsp/279

DOI: $10.4000 /$ rsp. 279

ISSN: 2610-4377

Publisher

Presses universitaires d'Orléans

\section{Printed version}

Date of publication: 1 March 2017

Number of pages: 17-34

ISSN: 1285-4093

\section{Electronic reference}

Franz d'Avis, «Exclamatives, Normalcy Conditions and Common Ground », Revue de Sémantique et Pragmatique [Online], 40 | 2016, Online since 01 March 2018, connection on 10 December 2020. URL : http://journals.openedition.org/rsp/279 ; DOI : https://doi.org/10.4000/rsp.279 


\title{
EXCLAMATIVES, NORMALCY CONDITIONS AND COMMON GROUND
}

\author{
Franz d'Avis \\ Johannes Gutenberg-Universität Mainz
}

\section{INTRODUCTION}

The starting point for the search for exclamative sentence types in a language is often the description of a certain function that utterances of sentences of that type would have. One formulation could be: With the use of an exclamative sentence, a speaker expresses that the state of affairs described by a proposition given in the sentence is not in accordance with his expectations about the world. ${ }^{1}$ Exclamative utterances may include an emotional attitude on the part of the speaker, which is often described as surprise in the literature, cf. Altmann (1987, 1993a), Michaelis/Lambrecht (1996), d'Avis (2001), Michaelis (2001), Roguska (2008) and others. Surprise is an attitude that is based on the belief that something unexpected is the case, see from a psychological point of view Reisenzein (2000).

The expression of disappointment of an expectation by the speaker can be related to the degree to which a certain property holds or to the proposition being the case, see (1a) and (1b).

(1) a. How fast he can play the solo!

b. Dass der ein Instrument spielt!

,It's surprising that he plays an instrument'

${ }^{1}$ These considerations are partly based on a talk I gave on the annual conference of the German society for linguistics (DGfS) 3/2012 and on d'Avis (2001, 2013a). See also Rett (2011) for a similar definition. I also thank the audience of the conference on « Exclamation and intersubjectivity », Nice 12/2015, Isabelle Ohles for help with the french abstract, and two anonymous reviewers for their constructive comments. 
In (1a) the speaker expresses his amazement at the degree to which the individual he refers to can play the solo fast. In (1b) it is the fact that der/he plays an instrument which is surprising for the speaker.

The relevant property can be explicit as in (1a) or implicit as in (2).

(2) What a house he has!

The amazing property of the house in (2) could be its dimension, its facilities, or whatever. The property must be derived from the context.

If we interpret exclamatives as expressing that a certain state of affairs in the actual world is not in accordance with what the speaker expects we can say that it is not in accordance with what the speaker takes to be normal. In this relation, we can class exclamatives with certain other constructions that in one way or another employ the speaker's ,conception of normality ' for semantic interpretation, for example concessive constructions or generic sentences. ${ }^{2}$ In these phenomena, we find a relation to the speaker's Normalcy Conceptions, expressed in a non-lexicalized, non-propositional way. With an exclamative, we understand that a speaker expresses that a certain proposition stands in contrast to his Normalcy Conceptions.

I will first explain what I mean by ,Normalcy Conception“. Then, I will argue on the basis of dass-exclamatives that exclamatives stand in a certain relation to the speaker's Normalcy Conceptions, in the case under discussion via the set of alternatives that is established by focus effects of the exclamative accent. Last I will show how the notion, that the speaker did not expect a certain proposition' (in our case the proposition that stands for the sentence grammatical meaning of the dass-exclamative) becomes part of the Common Ground.

\section{NORMALCY CONCEPTIONS}

Languages have different ways of explicitly expressing that a certain state of affairs conforms to what we consider normal. When Heinz brings his new girlfriend home for the first time and they find the cat, Henny, lying on the table, he could react to his girlfriend's questioning look like (3).

(3) Das ist normal.

'This is normal.'

If we want to express that something is in accordance with our idea about what is normal, we can also choose expressions like (4).

(4) a. Das ist üblicherweise/herkömmlicherweise/gewöhnlicherweise so.

'This is generally/customarily/commonly so'

b. Das ist in der Regel/im Allgemeinen so.

'This is so as a rule/in general'

\footnotetext{
${ }^{2}$ Cf. d'Avis (2013a, 2016a, 2016c).
} 
c. Das passiert regelmäßig.

'This happens regularly'

d. Das ist einfach so.

'That's simply the way it is'

The expressions in (3) and (4) have in common that a speaker explicitly says that he regards something as normal. There can be different reasons for why a speaker judges something to be normal. Considering (3), there can be different reasons why Heinz thinks that it is normal that his cat is lying on the table. Maybe, she is always lying there, or at least most of the time when he comes home. The occurrence of this state of affairs would have a high probability because of the statistical distribution in the past.

(5) Das ist normal. Da liegt sie fast immer.

'This is normal. She is almost always lying there'

Or maybe Heinz is not very strict with Henny, allowing her to move freely in the apartment. The table is the perfect spot for her to get a good view on the mice coming out of the hole in the corner. Without this lookout, it would not be necessary for the cat to often lie on the table, however, nothing would speak against her being there either.

(6) Das ist normal. Hier kann jeder machen, was er will, auch die Katze.

'This is normal. Everyone can do as he likes, even the cat'

Or maybe, the table is the only warm and sunny place in the apartment.

(7) Das ist normal. Katzen liegen gerne in der Sonne.

'This is normal. Cats like lying in the sun'

Here, Heinz explains the normality of the situation by stating that his cat behaves like every other cat. She is a typical cat.

Whatever the reason for Heinz' remark that the cat's behaviour is normal, he obviously has an idea about what counts as normal, common, following certain rules, about what he can expect in a certain situation. That does not mean that Heinz' utterance is true in a certain objective sense; this is not the point. The point is that Heinz utters (3) on the basis of certain conceptions about what he considers to be normal. Such conceptions I call 'Normalcy Conceptions' (NC).

Normalcy Conceptions are speaker-related and individual. What $A$ finds normal does not have to be normal for $B$. It does not follow, however, that there is no class of NC that is identical or more or less similar for most people in a society. If this was not the case, neither communication nor mutual action should be possible. I do not mean codes or rules that define how the world should be, but ideas about how the world is. We know that we must not steal, but it is still normal for us to lock up our doors and bicycles. 
An utterance like (3) is generally related to the speaker S: This is normal for $\mathrm{S}$. There are other possibilities to instantiate the person variable and there are further parameters that can be made explicit.

Consider (8).

(8) Das ist normal für Maria.

'This is normal for Maria.'

(8) is ambiguous. An utterance of (8) can mean that Maria considers whatever this refers to as being normal, or, alternatively, that $\mathrm{S}$ considers it to be normal with respect to Maria.

Expressions like normal are relative, they can relate to an individual, (9a), a time, (9b), a place, (9c), a certain group, (9d), or certain conditions, (9e). Generally speaking, they relate to a certain frame of reference that can be made explicit.

(9) a. Das ist normal für Maria.

'This is normal for Maria.'

b. Das war damals normal.

'This was normal at that time.'

c. Das ist normal im Dschungel.

'This is normal in the jungle.'

d. Das ist normal bei den Indianern.

'This is normal for Indians.'

e. Das ist normal, wenn xy der Fall ist.

'This is normal, if xy is the case.'

Without explicit instantiation of the parameters, these must be instantiated relative to the context, and we have to assume that the $\mathrm{NC}$ used are those of the speaker. $\mathrm{NC}$ belong to a certain individual and since we are interested in the role of $\mathrm{NC}$ in linguistic utterances, I concentrate on the assumption that every speaker maintains certain $\mathrm{NC}$. We can for now describe the $\mathrm{NC}$ of a speaker $\mathrm{S}$ as (a subset of) the propositions that are true in the worlds that $\mathrm{S}$ considers to be normal. ${ }^{3}$

$\mathrm{NC}$ are related to basic conceptual knowledge. It is a human trait to support NC. People classify the phenomena in their surroundings and reach generalizations, often without reasonable statistical knowledge, sometimes only based on a single instance. The one time experience: The neighbour's Rottweiler almost bit me can be the basis for a NC: Rottweilers like to bite people. But NC do not have to be based on personal experience. Probably in most cases, our NC are based upon knowledge we acquire from other people: parents, siblings, friends,

${ }^{3} \mathrm{I}$ have nothing to say about how $\mathrm{S}$ acquires his or her NC. This is partly a question for psychological research. 
teachers and of course from other sources like books or the internet.

Normalcy Conceptions (NC) have the following properties:

1. NC are speaker related, provided that no other possibility is explicitly given. Generally speaking, NC are relative, related to a certain frame of reference. In this sense they are local, which means NC are formulated for a certain part of reality that is restricted by the overall knowledge of the speaker and the capability of our sensory perception. Normally, we do not have a $\mathrm{NC}$ with respect to the behaviour of $\mathrm{H} 2 \mathrm{O}-$ molecules in elevated temperature (except maybe physicists or chemists), but we sure have an idea about the effect of hot steam on our skin.

2. An NC is meaningful for a speaker, if to assume it is more benefitting than not to assume it. Whether a benefit is really at hand is not the crucial point, but the speaker's conviction that there is one. This means also that it may be irrelevant for the speaker whether a certain $\mathrm{NC}$ is true in an objective sense or not.

3. NC allow exceptions. They are not universal propositions that are given up if a counter example shows up, but can be of relevance for a speaker, even if it is clear that they do not hold in all cases. If $\mathrm{NC}$ have this property, certain questions arise that I cannot go into, that probably belong to Psychology: How many exceptions does an NC allow? Are there $\mathrm{NC}$ that abide, even though there are no positive instances, i.e. only exceptions? If so, how do those NC come into being? ${ }^{4}$

If $\mathrm{NC}$ are formulated as propositions, we can regard them as the propositionalisation of (speaker-) normality. Normality should not be confused with normativity. Whereas normativity relates to given norms and to the way the world should be, normality describes a speaker's/person's notion of how the world is or rather how the world probably or generally is. It does not have to be a shared, superindividual notion. There can be agreement between the members of a group, but this is not constitutive for an NC. In the first instance it is related to an individual.

We can define Normalcy Conceptions like the Common Ground, as a set of propositions like (10):

(10) $\mathrm{NC}_{\mathrm{S}}:\{\mathrm{p} \mid \mathrm{p}$ is true in all possible worlds $\mathrm{S}$ considers to be normal $\}$

A speaker's S Normalcy Conceptions are represented by the set of all propositions $\mathrm{p}$ for which holds: $\mathrm{p}$ is true in all possible worlds the speaker $\mathrm{S}$ considers to be normal.

${ }^{4} \mathrm{NC}$ can also affect our perception of the world, making supporting evidence more salient than contradictory one. 
Now to exclamatives and related alternatives. I will restrict myself to dassexclamatives, but the findings carry over to other types of exclamatives, see d'Avis (2013a).

\section{ALTERNATIVES IN EXCLAMATIVES AND THEIR RELATIONTO THE SPEAKER'S NORMALCY CONCEPTIONS}

If a speaker utters an exclamative like (11)

\section{S1: Dass Maria DEN geheiratet hat! that Maria him married has ,Surprising that Maria married him!‘}

an addressee understands that there is a proposition $p$ describing the actual world (that Maria married him, him referring to the person Maria had married), which is in the case of dass-exclamatives presupposed. Moreover the addressee knows that there is a proposition $p$ ' (or a set of propositions) that describes what the speaker had expected, what the speaker takes to be normal with respect to a proper husband for Maria.

What do we know about these propositions?

1. The proposition $\mathrm{p}$ is the sentence grammatical meaning of the dass-exclamative. Even if the referent of , den/him ' is not made explicit in the utterance, we have to assume, that the speaker knows who he is. Otherwise the exclamation is not felicitous.

So, if the addressee asks (12a), S1 cannot answer (12b).

(12) a. S2: Who did she marry?

b. S1: I don't know.

2. The speaker must have an idea about who he would rather think that Maria has married, or at least about properties of a suitable husband, see (13).

(13) a. S2: Who do you think she should have married?

b. S1: Maybe Peter/maybe someone who is nicer.

The point is that there are alternatives available to the true proposition $\mathrm{p}$. How do we compute these alternatives and in what relation do they stand with respect to the proposition of the exclamative?

That is the place where the focal effects of the exclamative accent in dassexclamatives come into play. The main accent of an exclamative is the so-called exclamative accent. In the examples, the position of the exclamative accent is indicated by upper case. Experiments show that it can easily be distinguished from contrast accents or other focussing accents. Its particular properties are greater maxima with respect to the basic frequency, greater length and possibly a higher intensity, where the intensity maximum in the main accent syllable lies earlier than the F0-maximum, cf. Oppenrieder (1988), Batliner (1988). Altmann (1993b) explores the interrelation between various sentence types and focus- 
background-structure. To make a long story short: With respect to the question if the exclamative accent has focus-properties, if it has any focus effects in terms of reference to a set of alternatives, his answer is basically negative.

Since I will concentrate on dass-exclamatives here, I just quote Altmann with respect to the example in (14).

Dass ich DAS (aber auch) erleben muss!

'Surprising that I have to experience that!'

The exclamative accent on the demonstrative pronoun is according to Altmann (1993:34) without focus effects: "[...] eine fokale Interpretation scheidet mit hoher Sicherheit aus [a focal interpretation can be excluded with high certainty (my translation, $F D$ )]."

Nevertheless, I want to have another look at dass-exclamatives. For dassexclamatives, demonstrative pronouns are typical, which often bear the main accent, realised as an exclamative accent. If focus/focussing has to do with setting up a relation to alternatives or indicates the presence of alternatives, relevant for the interpretation of an utterance (cf. Rooth 1985, 1992; Jacobs 1988; Krifka 2007 and many others), than the following example shows, that different positions of the exclamative accent result in different sets of alternatives, see (15).

(15) a. S1: Der Karl hat dem Friedrich verraten, dass Heinz gelogen hat. ,Karl revealed to Friedrich that Heinz lied'

b. S2: Dass DER dem das verraten hat!

c. S2: Dass der DEM das verraten hat!

d. S2: Dass der dem DAS verraten hat!

'It is amazing that he revealed it to him!'

The accent on the demonstratives can be realised as an exclamative accent. I think we can safely assume that, if we are dealing with focus here, it is a minimal focus on the pronoun.

Intuitively, it seems to be obvious that $(15 \mathrm{~b}-\mathrm{c})$ express different things. However, if the function of focus is setting up a relation to sets of alternatives, why do we need these sets of alternatives in the case of exclamative utterances? Let us assume that the Common Ground is a set of propositions that are considered to be true by all interlocutors and all interlocutors know or at least assume that the others consider them also to be true. What happens to the Common Ground if a dass-exclamative like (15b) is uttered? Suppose we have two interlocutors, S1 and S2. The Common Ground is empty, except for certain world knowledge and knowledge about Karl, Friedrich and Heinz.

$\mathrm{S} 1$ asserts (15a). If the assertion succeeds, S2 accepts it, he does not disagree or question it, the interlocutors agree that the actual world is a world 
where the proposition 'that Karl revealed to Friedrich that Heinz has lied' is true. This proposition is added to the Common Ground, see (16).

$$
\mathrm{CG}_{0} \text { : }
$$

S1: Der Karl hat dem Friedrich verraten, dass Heinz gelogen hat.

$\mathrm{CG}_{1}$ : | that Karl revealed to Friedrich that Heinz has lied |

S2: Dass DER dem das verraten hat!

Now, S2 utters his exclamative sentence. S2: Dass DER dem das verraten hat! We understand that der refers to Karl, dem to Friedrich and das to the fact that Heinz had lied. The content, the proposition of S2's utterance is: that Karl revealed to Friedrich that Heinz has lied. This is obviously the same proposition that is already in the Common Ground: S1 did assert it and S2 had accepted it.

Or maybe, S2 didn't really accept the proposition, and the utterance of the dass-exclamative questions the truth of the proposition? Does S2's utterance have the same effect as (17)?

$$
\begin{aligned}
& \text { Ist das wirklich wahr? } \\
& \text { 'Is this really true?' }
\end{aligned}
$$

This does not seem to be the case, the effect of the exclamative utterance is different. Neither is the proposition asserted by S2's exclamative utterance. At least not, if we understand assertion like Stalnaker (1978), because it is already part of the Common Ground.

However, there are cases where one could think that a proposition that is already in the Common Ground is asserted (again). Consider (18) as a response to S1's assertion in (15a).

\section{S2: Karl hat dem das verraten. \\ 'Karl revealed it to him.'}

S2 uses a V2-declarative sentence, which is typically used for assertions. However, (18) need not be an assertion. It could be a kind of echo-question. In this case, we would probably recognise it by its special rising intonation and S1 would have to answer in an affirmative way. S2 could also just repeat the sentence that $\mathrm{S} 1$ had asserted, an acknowledgement of some sort or just to make the content clear for himself. Even in such a case, we would expect a certain kind of intonation.

If S2 in uttering (18) does not make it clear in one way or another that he is not asserting the proposition, he runs the risk of catching blame like (19).

(19) S1: Das habe ich doch gerade gesagt. Hörst du mir nie zu? 'I just said this. Don't you ever listen?'

Such a response would certainly be inappropriate after an exclamative utterance of the dass-sentence, see (20). 
S1: Karl hat Friedrich verraten, dass Heinz gelogen hat.

S2: Dass DER dem das verraten hat!

S1: \#Das habe ich doch gerade gesagt. Hörst du mir nie zu?

I think we can be fairly sure that in uttering the dass-sentence, S2 did not assert its proposition.

So, we have the following situation: S2 utters a sentence, the related proposition is already part of the Common Ground. In uttering the dass-exclamative sentence, it is not S2's goal that the proposition be added to the Common Ground. The speaker, in this case S2, expresses something that has to do with his attitude towards the relevant proposition. This is in principle what I described before, as the basic function of exclamatives: the speaker expresses that he, with respect to the relevant proposition, had expected something else. Expectation must not be understood here in the sense of S2 actively expecting something with respect to the proposition 'that Karl revealed to Friedrich that Heinz has lied'. S2 wasn't probably even aware that there was something Karl could have revealed to someone else. Why should he have a different expectation with respect to this state of affairs? I understand expectation of a speaker rather like (21) referring to the definition of Normalcy Conceptions I gave above.

The expectations of a speaker $\mathrm{S}$ are what follows from the speaker's Normalcy Conceptions $\mathrm{NC}_{\mathrm{S}}$.

Coming back to S2's exclamative utterance, what S2 expresses with the sentence in (22) in the above context

(22) S2: Dass DER dem das verraten hat!

is that the proposition 'that Karl revealed to Friedrich that Heinz has lied' is not compatible with his Normalcy Conceptions, that is, it may not follow from the set $\mathrm{NC}_{\mathrm{S} 2}$. By positioning the exclamative accent on the subject pronoun, something more is expressed, namely that there are alternatives to Karl, and if they take the place of Karl in the proposition this results in alternative propositions that are compatible with the set $\mathrm{NC}_{\mathrm{S} 2}$, maybe the ones in (23).

$\{$ that Anton revealed to Friedrich that Heinz has lied, that Berta revealed to Friedrich that Heinz has lied, that Caesar revealed to Friedrich that Heinz has lied

The accent on the pronoun indicates that there are alternatives, the illocution type exclamative indicates in what domain the alternatives are relevant. It is obvious that the alternatives are no longer live options with respect to the Common Ground. The Common Ground is already closed for this issue. For our chosen example with the exclamative accent on the subject pronoun, the speaker expresses that the proposition is false in the worlds he considers normal, whereas propositions with an alternative denotation for the expression in subject position are compatible with the set comprising his Normalcy Conceptions. 
That it makes sense to assume the existence of these alternatives and their relation to the speakers Normalcy Conceptions is shown by the fact, that this can be made explicit by the speaker, as we have seen in (13) above, also with respect to our recent example, cf. (24).

(24) a. S1: Der Karl hat dem Friedrich verraten, dass Heinz gelogen hat. ,Karl revealed to Friedrich that Heinz lied'

b. S2: Dass DER dem das verraten hat! I habe gedacht, Anton würde es ihm verraten.

'It is amazing that he revealed it to him! I thought Anton would reveal it to him.'

If we shift the exclamative accent to the other positions indicated above, the sets of alternatives change accordingly, see for the indirect object (25) and (26).

(25) a. S1: Karl hat dem Friedrich verraten, dass Heinz gelogen hat.

b. S2: Dass der DEM das verraten hat!

\{that Karl revealed to Dora that Heinz has lied, that Karl revealed to Emil that Heinz has lied, that Karl revealed to Gustav that Heinz has lied\}

I think, an expression with an exclamative accent can have focus properties in the sense of Krifka (2007:19), cf. (27).

A property $\mathrm{F}$ of an expression $\alpha$ is a Focus property iff $\mathrm{F}$ signals

(a) that alternatives of (parts of) the expression $\alpha$ or

(b) alternatives of the denotation of (parts of ) $\alpha$ are relevant for the interpretation of $\alpha$.

About part b. of (27), I talked above. I want to add that focus effects for an exclamative accent are not confined to minimal focus. Focus projection seems also possible. Consider (28).

(28) a. S1: Heinz hat seinem Sohn zum Geburtstag eine Uhr geschenkt.

'Heinz gave his son a watch for a birthday present

b. S2: Dass der seinem Sohn eine UHR schenkt!

'Amazing that he gives his son a watch!'

If S2 expected (29a) the focussed part is, eine Uhr'. If S2 expected (30a) the focussed part is 'eine Uhr schenkt'.

(29) a. \{that Heinz gives his son a book as a birthday present

b. S2: Dass der seinem Sohn [eine UHR] $]_{F}$ schenkt!

(30) a. $\quad$ that Heinz goes to the baths with his son\}

b. S2: Dass der seinem Sohn [eine UHR schenkt] $]_{F}$ !

Expression focus, as defined in (27a), is a bit harder. Krifka (2007) uses the example in (31).

Grandpa didn't [kick the BUcket $]_{F}$, he [passed aWAY] $]_{F}$. 
The point is that it is not the denotations of the alternative expressions that are different, it is in both cases the property DIE, but other aspects, here the connotations connected with the expressions. Maybe the following examples for exclamatives suffice.

(32) a. S1: Heinz war gestern total besoffen.

'Heinz was totally pissed yesterday'

b. S2: Dass der sich [beSOFfen $]_{F}$ hat, ich dachte der würde sich nur [beTRINken $]_{F}$.

'Amazing that he was pissed, I thought he would only get drunk.'

(33) a. S1: Ich bin beim Präsidenten und seiner Frau eingeladen.

'I've been invited by the president and his wife.'

b. S2: Dass der eine [FRAU] $]_{F}$ hat, ich dachte, der hätte eine [GeMAHlin $]_{F}$. 'Amazing that he has a wife, I thought he had a spouse.'

It seems that expression focus is also possible.

I have shown that exclamative accents can have focus effects. It is, however, not obvious that they must have them. If we look at other exclamative sentence types, for instance $w h$-exclamatives like (34), it seems hard to discover a focus effect.

[The mother of Heinz gave him an expensive watch as a present]

a. S: Was DIE dem geschenkt hat!

b. S: Was die DEM geschenkt hat!

'Amazing what she gave to him!'

The first point is that the relevant alternatives for the exclamation are computed via the $w h$-phrases. For (34a) and also for (34b) this means that the speaker expected that the referent of die/she, namely the mother of Heinz, gave Heinz something else for a present. I have the feeling that there is indeed a difference between (34a) and (34b), but it is not easy to see. Maybe, one would expect that (34a) is similar to (35).

(35) [The mother of Heinz gave him an expensive watch as a present]

S: Dass DIE dem DAS geschenkt hat!

'Amazing that she gave this to him!'

Here, it seems easier to understand a complex focus with alternatives like (36).

Ich hätte eher gedacht, dass sein VATer ihm ein AUto schenkt.

'I had rather expected that his father would give him a car as a present.'

It is possibly hard to align the computation of alternatives via question meaning to the computation of alternatives via focus in the course of language processing. Whatever the reasons, I think there is a difference between (34a) and (35). 
To sum up: The exclamative accent shows, at least with respect to dassexclamatives, focus effects. For different positions, different sets of alternatives come into play. And here, we find the connection to normality, i.e. the speaker's Normalcy Conceptions, in the interpretation of dass-exclamatives: The alternative propositions follow from the (set of) Normalcy Conceptions of the speaker. A restriction on this set is, that the basic proposition of the dass-exclamative may not follow from it. Even though the relation to the speaker's Normalcy Conceptions is not expressed explicitly in exclamatives, it can be shown that reference to the set of Normalcy Conceptions is necessary for all different kinds of exclamatives, cf. d'Avis (2013a). ${ }^{5}$ This relation is not part of the sentence grammatical meaning ${ }^{6}$ of the sentence that forms the basis of an exclamative utterance, so how can it be integrated in the overall interpretation? In the next section, I will argue that reference to the speaker's Normalcy Conceptions becomes part of the interpretation via the felicity conditions of exclamatives. To reach this conclusion, I will first consider the interaction between exclamations and context.

\section{EXCLAMATIONS AND CONTEXT CHANGE}

I think that Normalcy Conceptions can exist relatively independently of the Common Ground. That means, people can hold certain views about what they think is normal, even if it follows from the Common Ground that these views are wrong. But from the fact that the alternatives to the true proposition in dassexclamatives stand in a certain relation to a speaker's Normalcy Conceptions, these play an important role in the overall meaning of an exclamative utterance.

Consider the following example.

(37) a. S1: Maria hat Ludwig geheiratet.

'Maria married Ludwig.'

b. S2: Dass die DEN geheiratet hat!

,Amazing that she married him!'

5 An anonymous reviewer wondered how discrepancy with the speaker's Normalcy Conceptions can explain an example like (i) that could be felicitously uttered in a city where tall buildings are the norm, so that the speaker should have an idea about what to expect with respect to the height of buildings.

(i) My, what a tall building!

(ii) Boah, was für ein großes Gebäude!

There seem to be two possibilities. It could be that the speaker, being new in town, did not adapt his NC to the relevant norm, although in this case we would probably expect a plural noun phrase. On the other hand, it seems to me, at least for the German version in (ii), that the height of the building that is the reason for the utterance must be somehow remarkable compared to the idea of height of tall buildings the speaker may have established in such a city.

${ }^{6}$ For the sentence grammatical meaning of German wh-exclamatives see d'Avis (2001, 2002). 
S2 does not consider it normal, it does not follow from his Normalcy Conceptions 'that Maria married Ludwig'. He did rather expect alternatives for Ludwig, in any case did he not expect that Maria married Ludwig, see also Roguska (2008), who called this 'exclamative inference'.

That S2 expected something else, or did not expect what came true, is information that is added to the Common Ground. This information is communicated so that S1 could - with respect to (37b) - reply (38a) or (38b).

(38) a. S1: Was ist denn daran komisch? Das war doch zu erwarten. ,What is funny about that? Actually, it was to be expected.'

b. S1: Hast du wirklich etwas anderes erwartet? ,Did you really expect something else?'

The information that is added to the Common Ground is something like (39).

$$
\text { S2 did not expect that Maria married Ludwig. }
$$

How does this information find its way into the Common Ground? I will have a short look at three different ways and then talk about another possibility.

(i) Is (39) an implicature? An implicature that is not challenged may end up in the Common Ground as shared knowledge. Consider the scalar implicature in (40).

(40) a. S1: Einige haben geschlafen.

'Some were sleeping.'

$+>$ 'not all were sleeping'

b. S2: Wer war denn wach?

'Who was awake?'

S2's question makes only sense if S1 and S2 accept the implicature as shared knowledge. An answer like (41), should S1 utter it, is not acceptable.

(41) S1: \#Niemand war wach.

'Nobody was awake.'

An implicature can be cancelled, like in (42).

(42) S1: Einige haben geschlafen, wenn nicht alle.

'Some were sleeping, if not all.'

If (39) was an implicature, it should be possible to cancel it, see (43).

(43) S2: Dass die DEN geheiratet hat! \#Aber ich habe erwartet, dass sie ihn heiratet.

'Amazing that she married him. \#However, I expected, that she would marry him.'

The continuation in (43) sounds strange, if not contradictory. (39) does not seem to be an implicature.

(ii) Is (39) a presupposition? Could (39) be a presupposition that must be 
accommodated by the addressee? Normally, it is not acceptable to assert a proposition that was a presupposition of the preceding sentence, see (44).

(44) Meine Katze ist krank. \#Ich habe eine Katze.

'My cat is sick. \#I have a cat.'

We do not find this situation with (39), see (45).

Dass die DEN geheiratet hat! Das habe ich nicht erwartet.

'Amazing that she married him. I did not expect this.'

Quite the contrary, the continuation sounds perfectly natural, so (39) is probably not a presupposition.

(iii) Is (39) asserted after all? Asserted propositions can be stopped from entering the Common Ground. An interlocutor can negate it and so reject it, see (46).

(46) a. S1: Heinz ist ein Alkoholiker.

'Heinz is an alcoholic.'

b. S2: Nein, das stimmt nicht./Nein, Heinz ist kein Alkoholiker.

'No, that is not true./No, Heinz isn't an alcoholic.'

This is not possible for (39), see (47).

(47) a. S2: Dass die DEN geheiratet hat!

'Amazing that she married him!'

b. S1: \#Nein, du hast erwartet, dass Maria den Ludwig heiratet.

\#'No, you expected, that Maria would marry Ludwig.'

That (39) is asserted seems entirely impossible.

The addition of (39) to the Common Ground is neither carried out by implicature, nor by presupposition nor by assertion. ${ }^{7}$ Nevertheless, it is clear that this information is part of the Common Ground. It is negotiable and an addressee can react to its presence, see (48) as a reply to S2's (37b).

(48) S1: Wie kommst du darauf, dass Maria jemand anderen heiraten würde? 'How could you think Maria would marry someone else?'

\section{EXPECTATIONS AND FELICITY CONDITIONS}

A possible solution to this problem, that was also seen by Roguska (2008), is that (39) is added to the Common Ground because it is part of the felicity conditions of an exclamation.

That parts of the felicity conditions of speech acts can find their way into

7 An anonymous reviewer suggested that the proposition that the speaker does not expect the existing state of affairs is added to the Common Ground as a conventional implicature, cf. Castroviejo Miró (2008). While CIs share properties of the discussed inference, it is not really clear to me what lexical or constructional part is responsible for the $\mathrm{CI}$ in the sentences under discussion. 
the Common Ground can also be seen from other speech acts. I take it as evidence that they are part of the Common Ground, if they are negotiable. Let's have a look at the felicity conditions that Meibauer (2005) gives for assertion, see (49).

$$
\text { A asserted at } t \text { that } p \text { iff }
$$

(a) A uttered at $t$ the declarative sentence $\sigma$ meaning $p$,

(b) by uttering the declarative sentence $\sigma$, A presented $p$ as true,

(c) by uttering the declarative sentence $\sigma, \mathrm{A}$ M-intended that an addressee $\mathrm{B}$ to whom $\mathrm{A}$ uttered $p$ actively believes that $p$.

(49c) means that the speaker A wants B to believe that $p$ is the case. This ends up in the Common Ground and is directly negotiable. The addressee could reply to an assertion with utterances like (50).
a. Why should I believe this?
b. Warum sollte ich dir das abnehmen?
c. Und das soll ich dir abnehmen?

Or let's take the speech act 'promise'. A part of the felicity conditions of 'promise' is often described as (51).

$\mathrm{S}$ believes that A would prefer him to do what is said in $\mathrm{p}$ rather than not do it.

This part of the felicity conditions can find its way into the Common Ground. It is negotiable. Consider (52).

(52) a. S1: Ich verspreche dir, mit dem Saufen aufzuhören.

'I promise to stop drinking'

b. S2: Warum sollte ich das wollen?/ Du kannst von mir aus soviel saufen, wie du willst./Das ist mir doch egal, ob du säufst oder nicht.

'Why should I want this?/ You can drink as much as you want./I don't care whether you drink or not.'

So, parts of the felicity conditions of speech acts can be added as propositions to the Common Ground.

With respect to exclamations with a dass-sentence, we could assume the following conditions, see (53).

\section{Exclamation (dass-exclamative)}

An utterance of a speaker $\mathrm{S}$ counts as an exclamation (dass-exclamative) iff

(i) $\mathrm{S}$ utters a dass-exclamative sentences $\varepsilon$ with the meaning (proposition) $\mathrm{p}$;

(ii) p is already part of the Common Ground or can be accommodated without any difficulty;

(iii) $\neg$ p follows from the Normalcy Conceptions of S (i.e. S did not expect that p). 
(39) can be added to the Common Ground as part of the felicity condition, see (53iii), as in comparable cases in other speech acts. I do not think this is too absurd. Provided that the exclamation succeeds, an interlocutor is forced to accept that (53iii) is the case. It is a fact, just as Stalnaker's goat. The felicity conditions for dass-exclamatives can be generalized to all classes of exclamatives, s. d'Avis (2013a).

\section{FACIT}

I first talked about Normalcy Conceptions and then had a look at the question if the exclamative accent has focus properties and argued, at least for dassexclamatives, that the exclamative accent can signal the presence of alternatives. I made a suggestion in what way they could be relevant for the interpretation and how they relate to Normalcy Conceptions and the Common Ground. I ended with some remarks about the relation between the Common Ground and possible felicity conditions for a speech act 'Exclamation'.

\section{RÉFÉRENCES}

Altmann, H. (1987), «Zur Problematik der Konstitution von Satzmodi als Formtypen », in Satzmodus zwischen Grammatik und Pragmatik, Tübingen: Niemeyer, 22-56.

Altmann, H. (1988) (Hg.), Intonationsforschungen, Tübingen: Niemeyer.

Altmann, H. (1993a), «Satzmodus », in Syntax. Ein internationales Handbuch zeitgenössischer Forschung, Berlin, New York: Walter de Gruyter, 1006-1029.

Altmann, H. (1993b), « Fokus-Hintergrund-Gliederung und Satzmodus », in Wortstellung und Informationsstruktur, Tübingen: Niemeyer, 1-37.

Altmann, H. /Batliner, A./Oppenrieder,W. (Hgg.) (1989), Zur Intonation von Modus und Fokus im Deutschen. Tübingen: Niemeyer.

Batliner, A. (1988), « Der Exklamativ: Mehr als Aussage oder doch nur mehr oder weniger Aussage? Experimente zur Rolle von Höhe und Position des F0-Gipfels », in Intonationsforschungen, Tübingen: Niemeyer, 243-271.

Bless, H./Forgas, J.P. (2000) (eds.), The message within: The role of subjective experience in social cognition and behavior, Philadelphia, PA: Psychology Press.

Castroviejo Miró, E. (2008), « An expressive answer: Some considerations on the semantics and pragmatics of wh-exclamatives », in Proceedings from the Annual Meeting of the Chicago Linguistic Society 44/2, 3-17.

d'Avis, F. (2013a), Normalität und Sprache - Normalvorstellungen und ihre Rolle in bestimmten Konstruktionen des Deutschen, Habilitationsschrift, Johannes Gutenberg-Universität Mainz. 
d'Avis, F. (2016a), «Pejoration, normalcy conceptions and generic sentences », in Pejoration, Amsterdam, Philadelphia: Benjamins, 103-118.

d'Avis, F. (2016b), « Different Languages - Different Sentence Types? On Exclamative Sentences », in Language and Linguistics Compass 10/4, 159-175.

d'Avis, F. (2016c), « Satztyp als Konstruktion - Diskussion am Beispiel ,Konzessive Konditionalgefüge“ », in Satztypen und Konstruktionen, Berlin, Boston: De Gruyter, 267-295.

d'Avis, F.J. (2001), Über w-Exklamativsätze im Deutschen, Tübingen: Niemeyer.

d'Avis, F.J. (2002), « On the interpretation of wh-clauses in exclamative environments », in Theoretical Linguistics 28, 5-31.

Féry, C./Fanselow, G./Krifka, M. (2007) (eds.), The Notions of Information Structure, Interdisciplinary Studies on Information Structure 6, Potsdam: Universitätsverlag.

Finkbeiner, R./Meibauer, J. (2016) (Hgg.), Satztypen und Konstruktionen, Berlin, Boston: De Gruyter.

Finkbeiner, R./Meibauer, J./Wiese, H. (2016) (eds.), Pejoration, Amsterdam, Philadelphia: Benjamins.

Goldberg, A. (1996) (ed.), Conceptual Structure, Discourse and Language, Stanford, CA: Center for the Study of Language and Information.

Haspelmath, M./König, E./Österreicher, W./Raible, W. (2001) (eds.), Language Typology and Language Universals, Berlin, New York: Walter de Gruyter.

Jacobs, J. (1988), « Fokus-Hintergrund-Gliederung und Grammatik », in Intonationsforschungen, Tübingen: Niemeyer, 89-134.

Jacobs, J./Stechow, A. von/Sternefeld, W./Vennemann, T. (1993) (Hgg.), Syntax. Ein internationales Handbuch zeitgenössischer Forschung, Berlin, New York: Walter de Gruyter.

Krifka, M. (2007), « Basic Notions on Information Structure », in The Notions of Information Structure. Interdisciplinary Studies on Information Structure 6, Potsdam: Universitätsverlag, 13-55.

Meibauer, J. (1987) (Hg.), Satzmodus zwischen Grammatik und Pragmatik, Tübingen: Niemeyer.

Meibauer, J. (2005), « Lying and Falsely Implicating », in Journal of Pragmatics 37, 1373-1399.

Michaelis, L. (2001), « Exclamative constructions », in Language Typology and Language Universals, Berlin, New York: Walter de Gruyter, 1038-1050.

Michaelis, L. A./Lambrecht, K. (1996), « The Exclamative Sentence Type in English », in Conceptual Structure, Discourse and Language, Stanford, CA: Center for the Study of Language and Information, 375-389. 
Oppenrieder, W. (1988), «Intonation und Identifikation. Kategorisierungstests zur kontextfreien Identifikation von Satzmodi », in Intonationsforschungen, Tübingen: Niemeyer, 153-168.

Reis, M. (1993) (Hg.), Wortstellung und Informationsstruktur, Tübingen: Niemeyer.

Reisenzein, R. (2000), "The Subjective Experience of Surprise », in The message within: The role of subjective experience in social cognition and behavior, Philadelphia, PA: Psychology Press, 262-279.

Rett, J. (2011), «Exclamatives, degrees and speech acts », in Linguistics and Philosophy $34,411-442$.

Roguska, M. (2008), Exklamation und Negation, Berlin: Logos Verlag.

Rooth, M. (1985), Association with Focus, PhD thesis, GLSA, University of Massachusetts, Amherst.

Rooth, M. (1992), «A Theory of Focus Interpretation », in Natural Language Semantics 1, 75-116.

Stalnaker, R. (1978), «Assertion », in Context and Content, Oxford: Oxford University Press, 78-95.

Stalnaker, R. (1999): Context and Content. Oxford: Oxford University Press (original publication in: Cole, P. (ed.) (1978). Pragmatics. Syntax and Semantics 9).

Stalnaker, R. (2002), « Common Ground », in Linguistics and Philosophy 25, 701-721. 